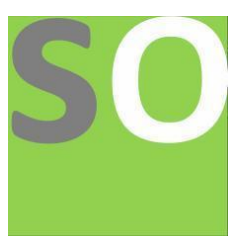

Article title: Are herbal drugs effective in COVID management? A review to demystify the current facts and claims Authors: Mohd Riyaz Beg[1], Barira Siddiqui[2], Pramod Waghmare[3], Shital Ghodinde[4], Snehal Bikkad[5] Affiliations: Dept. of Pharm. Sci. \& Tech., Institute of Chemical Technology, Mumbai, 400019, Maharashtra, India[1], Dept. of Commerce, Jamia Millia Islamia, Jamia Nagar, Okhla, New Delhi, Delhi 110025, India[2]

Orcid ids: 0000-0003-4734-5682[1], 0000-0003-1079-9488[3], 0000-0002-5825-3428[4]

Contact e-mail: menmy.1996@gmail.com

License information: This work has been published open access under Creative Commons Attribution License http://creativecommons.org/licenses/by/4.0/, which permits unrestricted use, distribution, and reproduction in any medium, provided the original work is properly cited. Conditions, terms of use and publishing policy can be found at https://www.scienceopen.com/.

Preprint statement: This article is a preprint and has not been peer-reviewed, under consideration and submitted to ScienceOpen Preprints for open peer review.

DOI: 10.14293/S2199-1006.1.SOR-.PPXFIF7.v2

Preprint first posted online: 19 November 2020

Keywords: Phytochemicals, Herbal drugs, Coronavirus, Covid-19 


\title{
Are herbal drugs effective in COVID management? A review to demystify the current facts and claims
}

Mohd Riyaz Beg ${ }^{1 *}$, Barira Siddiqui ${ }^{2}$, Pramod Waghmare ${ }^{1}$, Shital Ghodinde ${ }^{1}$, Snehal Bikkad ${ }^{1}$

1. Dept. of Pharm. Sci. \& Tech., Institute of Chemical Technology, Mumbai 400019, Maharashtra, India

2. Dept. of Commerce, Jamia Millia Islamia, Jamia Nagar, Okhla, New Delhi, Delhi 110025, India

Corresponding Author: Mohd Riyaz Beg

Address: Dept. of Pharm. Sci. \& Tech., Institute of Chemical Technology, Mumbai 400019, Maharashtra, India

Email: mohdriyazbeg@gmail.com

\begin{abstract}
Amid the SARS-CoV-2 pandemic, herbal medicines have received much attention in its evidence-based therapeutics. Scientists across the globe are integrating new research at an unprecedented fast pace for the discovery of novel molecules against this deadly viral disease. Ever since ancient times, phytochemicals have long been used traditionally for the cure of many viral diseases and lately many are being tested for their potential against the viral replications/transcriptions. The unmatched structural diversity of phytoconstituents may prove to be a gold mine for antiviral drug discovery. Many plants like Heteromorpha spp., Bupleurum spp, Scrophularia scorodonia, Artemisia annua, Pyrrosia lingua, Lycoris radiate, and Lindera agregata have also been reported to have antiviral potential against SARS-CoV. Recently many synthetic molecules like remdesivir, tocilizumab, favipirapir, dexamethasone, glucocorticoid, and hydroxychloroquine etc. have been extensively investigated for their potential against the SARS-CoV-2, likewise, various plant-based molecules such as scutellarein, silvestrol, tryptanthrin, saikosaponin B2, quercetin, myricetin, caffeic acid, psoralidin, isobavachalcone, and lectins-griffiths in were also found to be equally effective. Needless to mention that, the herbal medicines are a valuable and powerful source of chemical compounds which need further chemical modifications and appropriate in-vitro and in-vivo testings for establishing their safety and efficacy as potential drugs against the battle with coronavirus pandemic. In this review, we will try to highlight the potential phytochemicals candidates with their possible molecular targets against the SARS-CoV-2and demystify the myths behind the purported remedies such as herbal therapies, teas, essential oils, tinctures, and silver products such as colloidal silver that have no scientific evidence to prevent or cure COVID-19. Apart from that, this review will also de-fabricate the surgency of objectionable claims that are continuously reckoning towards the treatment of COVID-19 with hundred per cent surety and are propagated by several herbal firms.
\end{abstract}

Keywords: Phytochemicals, Herbal drugs, Coronavirus, COVID-19 


\section{Introduction}

Severe acute respiratory syndrome coronavirus 2 (SARS-CoV-2) is the virus of coronavirus family that causes coronavirus disease 2019 (COVID-19), a respiratory illness responsible for the COVID-19 global pandemic.COVID-19 is continuing its spread across the world, with over 41 million confirmed cases in 218 countries and more than 1.1 million deaths (WHO).Covid-19 spill-over at Huanan seafood market in Wuhan, China, was apparently successful in making its transition from animals to human. Coronaviruses are animal-borne zoonotic pathogens and can be transmitted through direct contact to humans. In most cases, though, these viruses were transmitted to humans via an intermediate host of animals. Person to person spread or community spread occurs because of coughing or sneezing or direct contact via droplets (Chatfield, Salehi, Sharifi-Rad, \& Afshar, 2018). It is estimated that all coronaviruses that caused epidemics (including COVID-19) originated in bats. Bats are the natural hosts of coronaviruses (Ge et al., 2013), (Hashemi-Shahraki et al., 2013). Coronaviruses (CoVs) are a group of enveloped viruses, having a positive single-stranded RNA genome and pathogenic. There are four major structural genes encode the nucleocapsid protein $(\mathrm{N})$, the spike protein $(\mathrm{S})$, a small transmembrane membrane protein $(\mathrm{SM})$, and the membrane glycoprotein (M) with an additional membrane glycoprotein (HE) in betacoronavirus HCoV-OC43 and HKU1 (Rottier PJM) and surrounds a disordered or flexible, probably helical, nucleocapsid. The viral membrane is unusually thick, probably because the carboxy-terminal region of the $\mathrm{M}$ protein forms an extra internal layer(Bárcena et al., 2009). At the level of the whole genome, Covid-19 is 96 per cent identical to a bat coronavirus (Zhou et al., 2020).

\section{Prominent symptoms of novel coronavirus disease}

The threemost common symptoms are fever, dry cough, and shortness of breath, while other symptoms include weakness, fatigue, sputum production, cough, body ache, tiredness, chills, chest pain, pain in throats, headache, haemoptysis, dyspnoea, and lymphopenia (Rothan\&Byrareddy, 2020)(Mao et al., 2020). Unique symptoms of COVID-19 may be Anosmia or Ageusia reported in approximately 3\% of individuals. Nausea, vomiting, diarrhoea, abdominal pain and loss of appetite are main gastrointestinal symptoms of COVID-19. Hospitalized patient experiences myalgias (15\%-44\%), headache, weakness $(25 \%)$, and rhinorrhoea (7\%). (Mao et al., 2020). Mean incubation period for development of symptoms after exposure to coronavirus found to be 5.2 days duration. The period from the beginning of covid-19 death symptoms ranged from 6 days to 41 days on median within 14 days. The time for development of symptoms depends on patient's age and patient immune system status (Q. Li et al., 2020). Dry cough, fever, dyspnoea and bilateral ground glass opacities on chest CT scans are common symptoms and signsof COVID-19 disease caused by beta coronaviruses, but there are some sole representing symptoms for COVID-19 that includes targeting of lower airway as evident by upper respiratory tract symptoms like rhinorrhoea, sneezing, and sore throat, anosmia or ageusia. (Rothan\&Byrareddy, 2020) Recent studies have also indicated that people infected with coronavirus have ongoing persistent symptoms in subsequent months as long COVID. 


\section{Virology \& Pathogenesis of the novel coronavirus}

Coronaviruses, a genus in the Coronaviridae family as per The International Code of Virus Classification and Nomenclature (ICVCN), are pleomorphic viruses (Perlman \&Netland, 2009).Coronaviruses are enveloped, positive single-stranded, large RNA viruses which infect humans, but also a wide variety of animals as it is a zoonotic virus. Tyrell and Bynoe first described coronaviruses in the year 1966, which cultivated the viruses from patients with common cold (Tyrrell \& Bynoe, 1966). They observed the similarity in the shape of virus to that of solar corona. So, their name is based on their morphology as spherical virions with a central shell and surface projections. There are Four subfamilies of coronaviruses including alpha, beta, gamma and delta coronavirus. While alpha- and beta-coronaviruses apparently come from bats, the gamma- and delta-viruses come from pigs and birds (Zhou et al., 2020), (GISAID). Human coronaviruses (HCoVs), HCoV-229E and NL63 are detected as the alpha coronavirus and MERS-CoV, SARS-CoV, HCoV-OC43 and HCoV-HKU1 are detected as the Beta coronavirus. Covid-19 belongs to the beta-coronavirus lineage B and is closely associated with the SARS-CoV virus (Zhou et al., 2020) (GISAID). This novel beta-CoV was then named "SARS-CoV-2" by the International Virus Classification commission (X. Li, Geng, Peng, Meng, \& Lu, 2020). The size of the Genome varies from $26 \mathrm{~kb}$ to $32 \mathrm{~kb}$. Amongst the seven subtypes of coronaviruses that can infect humans may cause severe illness and fatality, while alpha-coronaviruses may cause asymptomatic or mildly symptomatic infection (Zhou et al., 2020) (GISAID).

The replication and proliferation of SARS-CoV-2 virus took place efficiently in the human respiratory epithelial cells present throughout the respiratory tract, way started from nasal cavity to bronchi then to bronchioles, and finally the alveoli. Replication in lower respiratory tract causes development of severe lung disease while replication in upper respiratory tract causes efficient transmission between hosts (Rockx et al., 2020). Severe acute respiratory syndrome CoronaVirus2 (SARS-CoV-2)-induces host immune response and produces proinflammatory Cytokines and Chemokines(Wiersinga, Rhodes, Cheng, Peacock, \& Prescott, 2020).Inflammatory response is produced by infected Bronchial Epithelial cells, Type1 and type 2 alveolar pneumocytes, capillary endothelial cells (Wiersinga et al., 2020). In the early stage of inflammation signalling molecules i.e. cytokines are released by infected cells Tlymphocytes, monocytes, neutrophils and macrophages which are recruited by capillary endothelial cells. In the later stage of inflammation, continue inflammatory response results in alveolar interstitial thickening, increased vascular permeability and pulmonary oedema fills up the alveolar spaces with hyaline membrane formation (Wiersinga et al., 2020).Advanced increment in leukocyte count, abnormal breathing, and elevated plasma proinflammatory Cytokine and Chemokines like IL1- $\beta$, IL1RA, IL7, IL8, IL9, IL10, FGF2, GCSF, GMCSF, IFN $\gamma$, IP10, IL1- $\beta$, IL1, MCP1, MIP1 $\alpha$, PDGFB, MIP1 $\beta$, TNF $\alpha$, and VEGFA were found in COVID-19 infected patients. Most of the extreme cases admitted to the intensive care unit exhibited high levels of the anti-inflammatory cytokines IL2, IL7, IL10, GCSF, IP10, MCP1, MIP1 $\alpha$ and TNF $\alpha$, which are argued for the extent of disease (Rothan\&Byrareddy, 2020). 
Mechanism of coronavirus entry and replication in the eukaryotic cells

Mechanism of SARS-CoV fusion: SARS-CoV-2 virus targets cells through the viral structural spike(S) protein that binds to the angiotensin converting enzyme 2 (ACE2) receptor. The serine protease type 2 transmembrane serine protease (TMPRSS2) in the host cell activates SARS-CoV-2 S protein and further facilitates viral binding to host cell membrane (Wiersinga et al., 2020). Fusion is sequential proteolytic cleavage at 2 distinct sites (critical proteolytic cleavage event occurred at S protein) - cleavage at S1/S2 boundary promoting subsequent cleavage at $\mathrm{S} 2$ position which in turn leads to triggering of membrane fusion (Belouzard, Chu, \& Whittaker, 2009). Virus enters host cell via endocytosis and, the viral RNA genome is released into the cytoplasm (X. Li et al., 2020). ORF1a and ORF1ab are translated into polyproteins pp1a and pplab and structural proteins. The polyproteins are cleaved by 2 proteases, papain like protease (PLpro; corresponding to nsp3 [Rotavirus protein]), and main proteases, 3C like protease (3CLpro; corresponding to nsp5). Nsp rearranges membranes into double membrane vesicles, in which viral replication and transcription occurs (de Wit, van Doremalen, Falzarano, \& Munster, 2016). The newly formed envelope glycoprotein is inserted into the membrane of endoplasmic reticulum or Golgi and nucleocapsid is formed by combination of genomic RNA and nucleocapsid protein. Viral particle germinates, Transcripted sub-genomic RNAs produced in discontinuous manner and these virions fuse with plasma membrane to release the virus through exocytosis from infected cell (X. Li et al., 2020).

Antigen presentation in coronavirus infection: when virus enters the cells, its antigen will be presented to antigen presentation cells which is central part of the body's anti-viral immunity. Antigenic peptides are presented at major histocompatibility complex (MHC) and then recognized by virus specific cytotoxic $\mathrm{T}$ lymphocytes. besides gene polymorphism of Mannose binding lectin associated with antigen presentation are related to risk of corona virus infection(X. Li et al., 2020).

Humoral and cellular immunity: antigen presentation subsequently stimulates the body's humoral and cellular immunity which are mediated by virus-specific B and T cells. IgG and IgM antibodies are produced on exposure to SARS-CoV virus. IgM antibodies disappear at end of week 12 while IgG antibody can last for long time. (G. Li, Chen, \& Xu, 2003).

Cytokine storm in COVID-19: Acute respiratory Distress Syndrome (ARDS)is main immunopathological event for SARS-CoV2, SARS-CoV and MERS-CoV infections (Xu et al., 2020). Mechanism for ARDS is cytokine storm, in which large amount of proinflammatory cytokines and Chemokines are released from immune effector cells in SARS$\mathrm{CoV}$ infection and systemic inflammatory response is produced. Elevated levels of cytokines include INF-alpha, INF-gamma, IL-1 beta, IL-6, IL-12, IL-18, IL-33, TNF-alpha, TGFB and chemokines includes CCL2, CCL3, CCL5, CXCL8, CXCL9, CXCL10, etc (X. Li et al., 2020). Cytokine storm will instigate attack by immune system to body, causes ARDS, multiple organ failure and finally lead to death in severe cases of SARS-CoV-2 Infection (Xu et al., 2020). 


\section{Treatments available for COVID-19 (Modern-Synthetic drugs)}

We can start with the age-old notion that, "Prevention is better than cure". Till date the best practice to get safe from novel coronavirus disease is following safety guidelines that are issued by WHO and regional health authorities like social distancing, avoid unnecessary contacts, use of health hygiene practices, regular washing of hands, avoid touching face frequently, use of face shields and masks in public and crowed places, etc. But when we look on the side of therapeutics then, optimized supportive care is the only spine and remain the most favorable(1). While looking at the severity of the condition most of the researches going around are repurposing pre-existing preclinical and clinical data derived from SARS-CoV-1, MERS-CoV, and non-coronavirus diseases like Ebola virus disease, etc. but the reliability is low as it is not clear how well it can be inferred and extrapolated to SARS-CoV-2. The other challenge is that there is unavailability of Pharmacokinetic/Pharmacodynamic clinical data of anti-viral drugs which negates their use in the therapy of novel coronavirus. Further, to improve the impact of perceived activity the accessible data should be cautiously compared across the studies with potentially variable testing methodologies (1).

\section{Pharmacological treatments:}

As of now there are very limited synthetic drugs are available for the treatment of coronavirus disease. Amongst the available options majority are the result of the process called drug repurposing. To summarize, here are some of the approved treatments for combating coronavirus disease:

1. Remdesivir: It is the same drug which showed the antiviral activity during Ebola virus outbreak. It has a broad spectrum of antiviral activity against variety of viruses for e.g. Ebola, Nipah, Respiratory syncytial virus, and assorted class of coronaviruses with inclusion of SARS-CoV and MERS-CoV. Remdesivir is active as triphosphate form of a nucleotide and act as a substrate for viral RNA-dependent-RNA-polymerase complexes. It's resemblance with ATP molecule and competes with it during viral replication process. To be specific it also delay the chain termination in all the coronaviruses namely MERS-CoV, SARS-CoV, and SARS-CoV-2 (2). A 35-year old male in Washington, US was the first person who received remdesivir for the treatment of COVID-19 (3).The primary outcome after using remdesivir is the normalization of fever and oxygen saturation through day-14 in significant proportion of patients.

2. Chloroquine and hydroxychloroquine: Anti-malarial drugs with satisfactory antiinflammatory and immunomodulatory activities. First time in February, Wang et. al. showed the activity of Chloroquine against SARS-CoV-2 in-vitro with an EC $_{50}$ of $1.13 \mu \mathrm{M}$ in Vero E6 cell-line (4). Previously these drugs also showed demonstrated good activity against SARS-CoV-1 and MERS-CoV in various cell lines (5). On the same line, several clinical trials were conducted in China during this outbreak with $500 \mathrm{mg}$ of Chloroquine. As per the data collected, during mid-February it was came out as published research that, "thus far, results from more than 100 patients have 
demonstrated that chloroquine phosphate is superior to the control treatment in inhibiting the exacerbation of pneumonia, improving lung imaging findings, promoting a virus-negative conversion, and shortening the disease course according to the news briefing. Severe adverse reactions to chloroquine phosphate were not noted in the aforementioned patients." - Per Gao et.al. But due to the associated cardiovascular toxicity with chloroquine, a substitute compound which is structurally similar to chloroquine except a single difference of $-\mathrm{OH}$ group namely hydroxychloroquine paved the way to show efficacy against the SARS-CoV-2. It showed an improved tolerability as compared to chloroquine. It acts via inhibition of CME (Clathrin mediated endocytosis) which consequently inhibit TF/TFR1 (Tissue factor; Transferrin receptors 1) complex uptake; along with it the endosomal $\mathrm{pH}$ raises and inhibition of iron removal from TF (Tissue Factor) within endosomes takes place. The raised endosomal $\mathrm{pH}$ also paves the way for inhibition of iron release in the cytosol through DMT1 (Divalent metal-ion transporter 1) and TRPML1/MCOLN1 (Mucolipin 1). The lysosomal autophagy pathway impairment result in inhibited iron release from FT (Ferritinophagy) all these possible processes ultimately cause the cellular iron starvation and inhibits the viral life cycle. Simultaneously, Macrophagic polarization and immune-adaptive response also get modulated and help the body's immunity to boosted up (6).

3. Lopinavir/ritonavir: During this COVID-19 outbreak a combination of Protease inhibitors i.e. Lopinavir/Ritonavir was frequently proposed and prescribed. It is the same drug which is used in the treatment of HIV-AIDS. It is readily available at a economic price point as it one of the HIV medication under the WHO essential list of medicines (7). The off-label use of this combination was considered because it inhibits one of the crucial enzyme3-chymotrypsin-like protease (3CLpro) which is essential for processing of viral RNA leads to disruption of viral replication process. However, the SARS-CoV-2 is devoid of C2-symmetric pocket which is the major target of HIV protease inhibitors. Hence, raised several questions on the potency and efficacy of this combination (8).

4. Nitazoxanide: It is an antiviral agent with broad-spectrum of activity against influenza and other respiratory viral infections. It was highly prescribed and used during Middle East Respiratory Syndrome Coronavirus. It was one of the drugs under anti-protozoal class for the treatment of intestinal infection caused by protozoan Cryptosporidium parvum (registered in US as immediate release formulation) and Giardia intestinalis. Apart from the specific use it is general broad-spectrum antiparasitic agent use widely in south-east Asia (9). Though the mechanism of action is not fully understood but it selectively targets the viral haemagglutinin maturation process and block it at posttranslational stage in influenza viruses. It is also reported that it improves the natural innate immunity of host against viruses like HIV, rotavirus, and coronavirus (10). 
5. Tocilizumab: As an adjunct pharmacological treatment this humanized monoclonal antibody which have the potential to inhibit soluble and membrane-bound interleukin6 receptors. As IL-6 is one of the foremost immunogenic drivers in cytokine-release syndrome (CRS) and secreted by macrophages and monocytes. It was first approved for the treatment of rheumatoid arthritis and boomed recently as a corticosteroid sparing agent in chimeric antigen receptor T-cell therapy (CAR T) (Kotch C, Barrett $D$, Teachey $D T$ ). Many of the patients die because of overwhelming immune reaction to the virus leads to Cytokine storm an associated feature of CRS and Macrophage Activation Syndrome (MAS). CRS and MAS may cause acute respiratory distress syndrome in covid-19 patients with elevates plasma levels of ferritin, d-dimer and decreased platelets count. With due course of on-going researchers the data suggested that CRS, MAS and even sepsis can be eased with the use of biological therapies which target cytokines (11).

6. Corticosteroids: As per the literature search routine use of corticosteroids in COVID19 is not desirable. However, some findings suggest the use of methylprednisolone to cut-off the mortality rate in severe forms of acute respiratory distress associated with covid-19. The risk to benefit ratio is very high for these agents. These agents inhibit the inflammatory cascades. The major limitation of using them in the management of severe pneumonia due to coronavirus is the risk of secondary infection, and other physiological complications practically associated with their use(12).

7. Ribavirin +/- interferon: This therapy only used in the severe conditions where the risks outweigh the benefits. Ribavirin a nucleoside-guanosine analogue that inhibit the RNA synthesis. Classically used to treat Hepatitis-C in combination with interferons. The high risk of haematologic toxicity restricts its use in the moderately ill and hospitalised patients. As a matter of potency, ribavirin is 100 times less potent than the star performer remdesivir(4). On flipping the side, Interferons $(\alpha, \beta)$ are responsible to boost-up the innate antiviral immune response. They are proteins released endogenously or exogenously by the cells in response to detection of pathogens especially viruses. At the initial steps they interact to their receptors which generates pro- or anti-inflammatory responses as per the activation of particular set of genes. Studies and clinical trials showed that the treatment of INF- $\beta$ and INF- $\gamma$ could lead to reduction of viral infection. The limitation is polymorphic genetic responses which contributes to the restricted and partial effectiveness in genetically varied covid-19 patient population (Nancy R. Gough, PhD, 2020).

8. Oseltamivir and baloxavir: Antivirals designed for treatment of influenza draw the attention of various researchers for their prospective use in covid-19. Oseltamivir is an inhibitor of viral neuraminidases enzymes. These enzymes work on sialic acid residues and cleave them from the viral surface and cellular surface protein of infected cells. The ultimate effect of inhibition of these enzymes leads to inhibition of virion release and prevent new virion particles stomping. 
During the initial stages of multiplication of virus, a process called cap-snatching took place. In this process the viral polymerase binds to the pre-mRNA and endonucleases present in the viral polymerase break down the pre-mRNA and renovates them into capped RNA fragments. A new antiviral influenza drug i.e. Baloxavir inhibits this cap-dependent endonuclease enzyme. Hence, stopped the virus multiplication and reduce the viral load (Firstpost, COVID-19 Treatment, 2020).

9. Favipiravir: A non-FDA approved drug which created a vivid clatter around the world for showing significant results in curbing the covid-19 symptoms in the patients in the preliminary studies. It is currently evaluated for its efficacy and safety in Clinical Trial NCT04273763 for its usefulness in COVID-19 patients. It acts via RNA-dependent RNA polymerase inhibition and categorised as broad spectrumantiviral agent (15)(16).

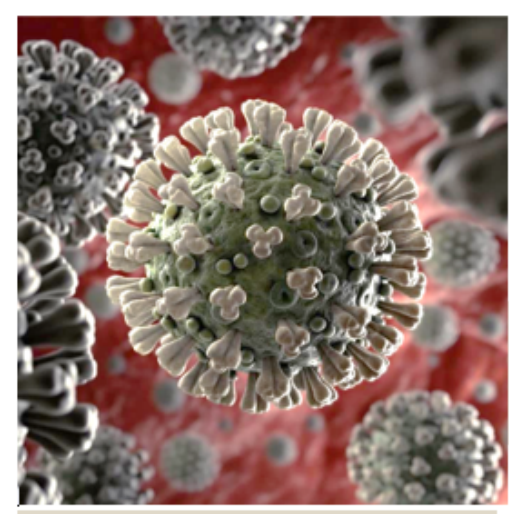

Remdesivir is currently the only medication approved by the FDA for the treatment of coronavirus disease 2019 (COVID-19). Dexamethasone is a common corticosteroid (steroid) medication. RECOVERY, a randomized clinical trial in the UK, is studying many medications, including dexamethasone, to see if any are effective against COVID-19. Convalescent plasma is collected from people who have recovered from COVID-19. It is then transfused into someone with an active coronavirus infection. It is thought that antibodies found in the convalescent plasma can help fight the coronavirus infection.

Hydroxychloroquine and chloroquine $\mathrm{A}$ few small studies initially suggested that they may also be helpful for treating hospitalized patients

\section{Treatments for COVID-19}

There is no cure or vaccine for COVID-19 at this. time. There are currently more than 100 COVID-19 vaccine candidates under development, with a number of these in the human trial phase.

- Preclinical: 154

- Phase I: 36

- Phase II: 16

- Phase III : 11

- Approved: 0

with mild cases of COVID-19 Azithromycin in combination with hydroxychloroquine was found to be protective as $93 \%$ of

The FDA recently created a new emergency program,

Coronavirus Treatment

Acceleration Program (CTAP), aimed at speeding up research for the development of COVID19 treatments. patients cleared the virus after 8 days. Tocilizumab helps to calm down the immune system and is believed to also help with managing cytokine storm
Interferons are signaling proteins (cytokines). In vitro studies have shown that interferon-alfa (IFN- $\alpha$ ) and interferon-beta (IFN- $\beta$ ) have antiviral activity against the SAR $\mathrm{CoV}-2$ virus.

Favipiravir is an antiviral medication approved in Japan and China for the flu. In vitro studies have shown that high doses of favipiravir were able to prevent human cells from being infected with SARS-CoV-2.

Tamiflu is an antiviral medication used for influenza (flu). Results from a hospital in Wuhan, China were not promising.
AstraZeneca and

Johnson \& Johnson

vaccines are among

several candidates in

final-stage testing

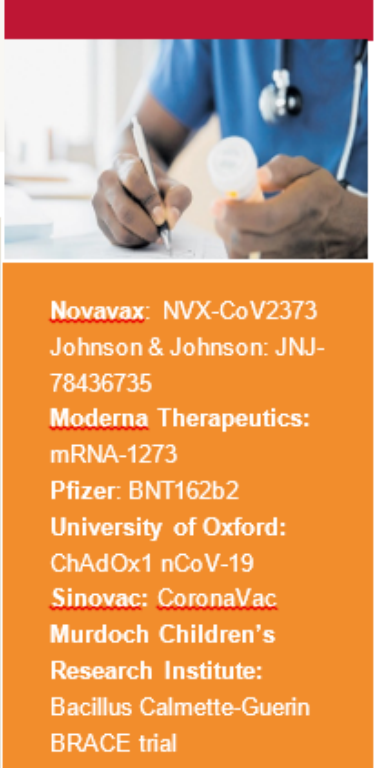

Figure 1: Various Therapeutics currently using or under trial for treating COVID-19 


\begin{tabular}{|c|c|c|}
\hline \multirow{6}{*}{$\begin{array}{l}\text { REMDESIVIR } \\
\text { CATEGORY: Antiviral } \\
\text { STATUS IN INDIA: Approved } \\
\text { WHAT IT DOES: Speeds } \\
\text { recovery by shutting down } \\
\text { viral replication in the body. } \\
\text { Hospitalised patients given } \\
\text { remdesivir were discharged } \\
\text { within } 11 \text { days on average, } \\
\text { compared to } 15 \text { days for } \\
\text { patients on standard care. } \\
\text { WHEN SHOULD IT BE USED: } \\
\text { Given to hospitalised patients } \\
\text { on oxygen with moderate } \\
\text { Covid-19. } \\
\text { MODE OF DELIVERY: Intrave- } \\
\text { nously in ICU; Gilead Sciences } \\
\text { working on an inhaler. } \\
\text { GLUCOCORTICOIDS } \\
\text { CATEGORY: Corticosteroid } \\
\text { STATUS IN INDIA: Approved } \\
\text { WHAT IT DOES: Calms acute } \\
\text { inflammatory response to slow } \\
\text { disease progression by preventing } \\
\text { the body from pumping out } \\
\text { inflammatory chemicals. } \\
\text { WHEN SHOULD IT BE USED: } \\
\text { For severely ill patients with } \\
\text { progressive deterioration of } \\
\text { oxygenation indicators, rapid } \\
\text { Worsening of imaging, and } \\
\text { cytokine storm } \\
\text { MODE OF DELIVERY: Intravenous }\end{array}$} & \multirow[b]{2}{*}{$\begin{array}{l}\text { DEXAMETHASONE } \\
\text { CATEGORY: Corticosteroid } \\
\text { STATUS IN INDIA: Not approved } \\
\text { for Covid-19, approved to treat } \\
\text { rheumatoid arthritis, allergies. } \\
\text { WHAT IT DOES: Modulates } \\
\text { immune-mediated lung injury } \\
\text { and slows progression to } \\
\text { respiratory failure and death. } \\
\text { It cut the risk of death by a third } \\
\text { for patients on ventilators. }\end{array}$} & \multirow[b]{2}{*}{$\begin{array}{l}\text { For those on oxygen, it cut } \\
\text { deaths by a fifth. } \\
\text { WHEN SHOULD IT BE USED: } \\
\text { Given to severely ill patients on } \\
\text { invasive ventilation or } \\
\text { oxygenation. It does not help } \\
\text { with mild or moderate disease. } \\
\text { MODE OF DELIVERY: } \\
\text { Intravenous in ICU, as tablet for } \\
\text { less seriously ill patients. }\end{array}$} \\
\hline & & \\
\hline & \multirow[b]{2}{*}{$\begin{array}{l}\text { FAVIPIRAVIR } \\
\text { CATEGORY: Antiviral } \\
\text { STATUS IN INDIA: Approved } \\
\text { WHAT IT DOES: This broad-spec- } \\
\text { trum antiviral works by } \\
\text { selectively inhibiting RNA } \\
\text { polymerase, which is needed for } \\
\text { the replication of Sars-CoC-2 } \\
\text { inside the human body to cause } \\
\text { severe disease. } \\
\text { WHEN SHOULD IT BE USED: For } \\
\text { mild to moderate disease } \\
\text { MODE OF DELIVERY: Oral tablets }\end{array}$} & \multirow[b]{2}{*}{$\begin{array}{l}\text { TOCILIZUMAB } \\
\text { CATEGORY: Monoclonal } \\
\text { antibody } \\
\text { STATUS IN INDIA: Approved } \\
\text { WHAT IT DOES: Calms the } \\
\text { aberrant hyper-immune } \\
\text { response called cytokine storm } \\
\text { by acting against inflammatory } \\
\text { chemicals to fight infection. } \\
\text { WHEN SHOULD IT BE USED: } \\
\text { Moderate to Severe disease } \\
\text { MODE OF DELIVERY: } \\
\text { Intravenous drip }\end{array}$} \\
\hline & & \\
\hline & \multicolumn{2}{|c|}{ CONVALESCENT PLASMA } \\
\hline & $\begin{array}{l}\text { CATEGORY: Plasma therapy } \\
\text { STATUS IN INDIA: Approved for } \\
\text { restricted use } \\
\text { WHAT IT DOES: Infection-fight- } \\
\text { ing antibodies from the blood of } \\
\text { recovered people given to ill } \\
\text { patients to boost their immunity }\end{array}$ & $\begin{array}{l}\text { WHEN SHOULD IT BE USED: For } \\
\text { patients with moderate disease } \\
\text { whose oxygen requirement is } \\
\text { progressively increasing despite } \\
\text { the use of steroids. } \\
\text { MODE OF DELIVERY: } \\
\text { Transfusion }\end{array}$ \\
\hline \multicolumn{3}{|c|}{ HYDROXYCHLOROQUINE } \\
\hline $\begin{array}{l}\text { CATEGORY: Anti-malaria } \\
\text { STATUS IN INDIA: Approved } \\
\text { WHAT IT DOES: Found to inhibit } \\
\text { the activity of Sars-Cov-2 in lab } \\
\text { studies by decreasing the } \\
\text { acidity in endosomes, which are }\end{array}$ & $\begin{array}{l}\text { compartments inside cells that } \\
\text { some viruses co-opt to enter } \\
\text { cells and cause infection. } \\
\text { WHEN SHOULD IT BE USED } \\
\text { Prophylaxis for high-risk close } \\
\text { contacts, healthworkers and } \\
\text { frontline workers who have had }\end{array}$ & $\begin{array}{l}\text { unprotected exposure to } \\
\text { infection; people with mild } \\
\text { disease at start of infection. It is } \\
\text { not approved for severely ill } \\
\text { patients. } \\
\text { MODE OF DELIVERY: Oral } \\
\text { tablets }\end{array}$ \\
\hline
\end{tabular}

Figure 2: Repurposed and new drug treatments available for COVID-19 [Credits: Hindustan Times (17)]

Some other agents under investigation for COVID-19 treatment

The below table contains the agents that are under investigation or theoretically considered for COVID-19 management. Due to lack of strong evidences these agents should be avoided.

Table 1: Miscellaneous drugs for covid-19 therapy

\begin{tabular}{|l|l|l|l|l|}
\hline $\begin{array}{l}\text { S. } \\
\text { No }\end{array}$ & Agent & $\begin{array}{l}\text { Mechanism of action } \\
\text { against SARS-CoV-2 }\end{array}$ & Other comments & Reference \\
\hline 1 & Anakinra & $\begin{array}{l}\text { IL-1 receptor } \\
\text { antagonist }\end{array}$ & $\begin{array}{l}\text { No clinical trials are } \\
\text { enrolling for this agent }\end{array}$ & $(18)$ \\
\hline 2 & Umifenovir & $\begin{array}{l}\text { The drug target and } \\
\text { mechanism of action } \\
\text { of umifenovir against } \\
\text { SARS-CoV-2 are } \\
\text { unknown }\end{array}$ & $\begin{array}{l}\text { This drug has a good } \\
\text { safety profile and acts } \\
\text { by preventing entry of } \\
\text { virus into human cells } \\
\text { and also by priming }\end{array}$ & $(19) ;(20)$ \\
\hline
\end{tabular}




\begin{tabular}{|c|c|c|c|c|}
\hline & & & $\begin{array}{l}\text { the immune system. } \\
\text { (Govt. of India) }\end{array}$ & \\
\hline 3 & Baricitinib & $\begin{array}{l}\text { Janus kinase family } \\
\text { enzyme inhibitor }\end{array}$ & $\begin{array}{l}\text { Screened as a } \\
\text { suggestion for covid- } \\
19 \text { treatment by } \\
\text { Artificial Intelligence } \\
\text { and Eli Lilly } \\
\text { Announces Phase } 3 \\
\text { Clinical Trial of } \\
\text { Baricitinib for } \\
\text { COVID-19 Patients }\end{array}$ & (21) \\
\hline 4 & Bevacizumab & $\begin{array}{l}\text { Recombinant } \\
\text { Humanized } \\
\text { Monoclonal antibody, } \\
\text { avoids VEGF } \\
\text { association with } \\
\text { endothelial receptors. }\end{array}$ & $\begin{array}{l}\text { Evaluated under } \\
\text { clinical trial in China } \\
\text { for COVID-19 } \\
\text { (NCT04275414) }\end{array}$ & (22) \\
\hline 5 & Brilacidin & $\begin{array}{l}\text { A host defense peptide } \\
\text { mimetic agent }\end{array}$ & $\begin{array}{l}\text { In clinical trial by } \\
\text { Innovation } \\
\text { Pharmaceuticals. } \\
\text { Recently, company } \\
\text { has announced the } \\
\text { testing of molecule } \\
\text { against COVID-19. }\end{array}$ & $\begin{array}{l}\text { (23)http://www.ipharmi } \\
\text { nc.com/brilacidin-1 }\end{array}$ \\
\hline 6 & $\begin{array}{l}\text { Convalescent } \\
\text { plasma }(\mathrm{CPT})\end{array}$ & $\begin{array}{l}\text { CPT exploits aexplicit } \\
\text { titer of virus-specific } \\
\text { antibodies in the } \\
\text { plasma of the } \\
\text { convalescent } \\
\text { individuals. That } \\
\text { provides a passive } \\
\text { immunity to the } \\
\text { patient receiving the } \\
\text { infusion. }\end{array}$ & $\begin{array}{l}\text { Previously, this } \\
\text { method has been } \\
\text { fruitfully used during } \\
\text { the SARS-CoV-1 and } \\
\text { H1N1 outbreak. }\end{array}$ & (24) \\
\hline 7 & Disulfiram & $\begin{array}{l}\text { It showed the activity } \\
\text { of competitive } \\
\text { inhibition of Papain } \\
\text { like proteases of } \\
\text { SARS. }\end{array}$ & No clinical data exists & (25) \\
\hline 8 & $\begin{array}{l}\text { Cobicistat/Daru } \\
\text { navir }\end{array}$ & $\begin{array}{l}\text { HIV-1 protease } \\
\text { inhibitor. }\end{array}$ & $\begin{array}{l}\text { Currently, evaluated } \\
\text { under NCT04252274 } \\
\text { clinical trial. }\end{array}$ & (26) \\
\hline
\end{tabular}




\begin{tabular}{|c|c|c|c|c|}
\hline 9 & Eculizumab & $\begin{array}{l}\text { Humanized } \\
\text { Monoclonal IgG } \\
\text { antibody. Prevents the } \\
\text { formation of } \\
\text { membrane attack } \\
\text { complex by binding to } \\
\text { complement protein } \\
\text { C5 }\end{array}$ & $\begin{array}{l}\text { Under evaluation; } \\
\text { Clinical trial } \\
\text { NCT04288713 for } \\
\text { covid-19. }\end{array}$ & (27) \\
\hline 10 & Galidesivir & $\begin{array}{l}\text { Nucleoside RNA } \\
\text { polymerase inhibitor }\end{array}$ & $\begin{array}{l}\text { Reported antiviral } \\
\text { activity (broad } \\
\text { spectrum). In pipeline } \\
\text { of Biocryst Pharma }\end{array}$ & (28) \\
\hline 11 & Nelfinavir & $\begin{array}{l}\text { An HIV-1 protease } \\
\text { inhibitor }\end{array}$ & No clinical data exist & (29) \\
\hline 12 & Niclosamide & $\begin{array}{l}\text { Block endocytosis of } \\
\text { SARS-CoV-2 }\end{array}$ & $\begin{array}{l}\text { Anthelminthic drug } \\
\text { repositioning }\end{array}$ & (30) \\
\hline 13 & Vitamin C & $\begin{array}{l}\text { Intravenous vitamin C } \\
\text { for reduction of } \\
\text { cytokines storm in } \\
\text { acute respiratory } \\
\text { distress syndrome }\end{array}$ & $\begin{array}{l}\text { Ongoing clinical trial } \\
\text { on Vitamin C in China } \\
\text { for treatment of } \\
\text { COVID-19 } \\
\text { (NCT04264533) }\end{array}$ & (31) \\
\hline 14 & Sofosbuvir & $\begin{array}{l}\text { Sofosbuvir inhibits the } \\
\text { hepatitis C NS5B } \\
\text { protein which is a viral } \\
\text { polymerase }\end{array}$ & & (32) \\
\hline 15 & Sarilumab & $\begin{array}{l}\text { IL-6 receptor } \\
\text { antagonist }\end{array}$ & $\begin{array}{l}\text { Under clinical trial in } \\
\text { New York }\end{array}$ & (33) \\
\hline 16 & Ivermectin & $\begin{array}{l}\text { It acts as an inhibitor } \\
\text { of nuclear transport } \\
\text { via the importin } \alpha / \beta 1 \\
\text { heterodimer which is } \\
\text { responsible for the } \\
\text { translocation of } \\
\text { various viral species } \\
\text { proteins like HIV-1, } \\
\text { SV40 and it is } \\
\text { essential for their } \\
\text { replication. }\end{array}$ & $\begin{array}{l}\text { Recommended by Pan } \\
\text { American Health } \\
\text { Organization. }\end{array}$ & $(34) ;(35)$ \\
\hline
\end{tabular}

Verily, these drugs are showing some symptomatic relief in infected patients but the clinical outcomes are not promising for example, on $4^{\text {th }}$ July 2020 WHO International Steering Committee passed the judgement that, "hydroxychloroquine and lopinavir/ritonavir produce 
little or no reduction in the mortality of hospitalized COVID-19 patients when compared to standard of care." (36)

Confinements due severe adverse effects and anecdotal unsubstantiated reporting of falsified synthetic-chemical agents for covid-19 treatment ignite the spark to search and rediscover the natural resources. As we all know that, the mother nature is the treasure of wonderful medicinal resources and researchers across the global are focusing of natural resources to find out prospective treatment which not only obliterate the symptoms but also help the human body to get cured with a greater efficacy.

\section{Why shift to natural products? (A brief account on use of Phytoconstituents as drugs)}

The evidence from history of the use of herbal remedies dated back from the era of Neanderthal man. The decade of 1960s, just after the thalidomide disaster observed an increase surge in the use of herbal drugs due to common notion of the time that synthetic drugs may cause iatrogenic adverse effects (37). Approximately, 75\% of the plant based therapeutic drugs used across the globe and it is surprising to note that $70 \%$ of drugs used as modern therapeutics are discovered from natural resources. Either they used in directly in their native form after isolation and purification or they a number of synthetic analogues have been developed from architype phytoconstituents derived from plant sources (38).

When we look the statistics, the number tells us the truth of the importance of natural products:

- $60 \%$ of Anticancer drugs available in market or under trails are derived from natural products

- $80 \%$ of immunosuppressants, cardiovascular, antimicrobials are based on plant sources.

- Around, 25-30\% of prescription drugs around the world are originally derived from natural entities.

- Out of 252 drugs 30 drugs found in essential list of medicines of WHO are derived from natural sources.

- Ayurveda utilizes around $1200-1800$ plants

- Unani system consists of 400-700 medicinal plants

- Siddha uses 500-900 plants

\section{Effectiveness of herbal drugs}

In the recent past due to the awareness towards the scientific evidence-based medicines the fields like clinical research, quality assurance and pharmacovigilance boosted up which demands a clinically proven and effective medicine for the use of masses without substantial adverse or side effects. Fortunately, at both international and national level various natural products have undergone stringent scientific pre-clinical and clinical studies as medical agents and concluded to be efficacious for treating the illness and promoting the health. As per a report published by AYUSH, Govt. of India, around 4175 clinical trials are undergoing based on natural products, 8514 drugs based on plants and herbs are under pre-clinical 
research, 6002 drugs research and 2926 basic research related to plants used as medicinal agents are going on at several institutes and organizations.

In the below section we tried to review a number of plants derived molecules based on the targeted drug approach for their action against the COVID-19.

\section{Plant based Molecules having activity against SARS-CoV-2}

As the matter of fact, SARS-CoV-2 has positive-sense single-stranded RNA with the largest RNA genome and as its genomic sequence noteworthy similarity to that of SARS-CoV. Hence antiviral drugs used to treat SARS and MERS are now being utilized for COVID-19 treatment. The efficacy of repositioned synthetic drugs such as lopinavir/ritonavir, darunavir/umifenovir, oseltamivir, favipirapir, remdesivir as well as some other drugs such as chloroquine, hydroxychloroquine, azithromycin, tocilizumab, interferon- $\beta$, hydroxychloroquine is still under evaluation and severe side effects is a cause of concern. Scientists are struggling to discover new curefor this deadly novel-coronavirus. This accentuated natural products as a treatment option for COVID-19 which could be both safe and effective and having immense medicinal properties such aspotent antiviral, immunomodulatory, anti-inflammatory, and antioxidant activity. Natural compounds as well as with their synthetic or semisynthetic analogues may have benefit as therapeutic agents against coronavirus infection as they provide a wealth of chemical diversity displaying antiviral properties and can be utilized not only for strengthening our immune system but also killing the pathogens at the same time.As well as their natural amiability either in the form of standardized extract or as a pure compound based on ethnopharmacological assets plays a significant role in new drug development. Various drugs contribution from natural origin is significant as they have shown antiviral activity against number of viruses such as Influenza virus, Zika virus, Dengue virus, Japanese encephalitis virus, Herpes simplex virus, Hepatitis B and C virus, Respiratory syncytial virus, and HIV including various coronaviruses. Secondary active metabolites of natural origin that show promise for the inhibition of coronavirus in humans are majorly polar compounds contained a conjugated fused ring structure mostly are polyphenols (39). Let us discuss in a bit detail about these molecules from natural origin and on what basis are they going to be use against the battle of coronavirus?

\section{In-silico approaches}

Plant extract and plant derived active constituents exhibit distinct antiviral mechanism towards different viruses. Some of the phytochemicals target the viral envelope or the membrane proteins while other prevent the viral attachment to host cell as well as some phytochemicals denature the crucial viral enzymes required for viral genome replication and assembly. Recent advancement in computational approaches are playing an important role in the screening of drug and their design. To facilitate the speedy development of biologically active drug-like molecules that target multiple viral enzymes of the viral replication cycle for SARS-CoV-2. It is vital to employ in silico approaches in response to the global pandemic situation. These computational models determine the free binding of energy between a receptor and a ligand and with a lower free binding energy showing a stronger bond between 
the ligand and receptor. It is also beneficial for reducing the high costs and length of time required with physically screening large library of compounds or plant extracts for bioactivity. Further, these potential compounds can be assessed preliminarily through appropriate in vitro and in vivo models for their safety and therapeutic efficacy in lab. . The following are some of the relevant targets on which natural compounds can mark their actions:

\section{Mpro}

Mpro (molecular weight $34 \mathrm{kDa}$ ) also called as the 3C-like protease (3CLpro) is the main $\mathrm{CoV}$ protease, which plays an essential role in virus replication and controlling host cell response. The COVID-19 virus genome consists of $\sim 30,000$ nucleotides and its replicase gene encodes ppla and pplab overlapping polyproteins necessary for viral replication and transcription. Mpro has highly conservative substrate-recognition pocket and responsible for the proteolytic cleavage of the polyprotein at no less than 11 conserved sites to release functional polypeptides. Therefore, Mpro stand as an attractive target for developing antiviral drugs against coronavirus.

Two compounds named Robustone and Schizolaenone B showed binding affinity value of $7.8 \mathrm{kcal} / \mathrm{mol}(\mathrm{Ki}=1.889 \mu \mathrm{M})$ and minimum band energy gaps exhibited strong potential as inhibitors of Mpro activity. The properties such as drug likeness, binding interaction with ligand, reactivity carried out by computational based approaches through ADMET, molecular docking and DFT-based computations. Robustone is a flavonoid compound having antioxidant property which was used as inhibitor against the protease of dengue virus and according to computer aided study exhibited great binding affinity against Mpro of SARSCoV-2.Schizolaenone B is a tetrahydroxy flavanone isolated from Schizolaena hystrix has a role as a metabolite and an antineoplastic agent. In addition to this Osajin, IsosilybinA, Silybin A, Silydianin and Isopomiferin also showed the highest reactivity with the Mpro of 2019-nCoV in correlation with binding affinity (40).

The phytochemicals such as hypericin, cyanidin 3-glucoside, baicalin, glabridin, and aketoamide-11r exhibited the highest binding affinity and strong interactions with both or at least one of the catalytic residues (Cys145 and His41) of the main protease (41).Hypericin is an anthraquinone derivative and naturally occur in the yellow flower of Hyperium perforatum and has shown antiviral property by preventing the replication of encapsulated viruses. Along with this it has antidepressant, antineoplastic and immunostimulating activities. $\beta$-Sitosterol is well known for its multiple biological actions and is isolated from n-hexane extract of the M. calabura bark for phytochemical analysis. $\beta$-Sitosterol has stronger binding affinity for SARS-CoV-2 Mpro than favipirapir as it interacts with greater number of amino acids and forms more Van-der-waal forces with target molecule (42). In silico analysis demonstrated that the terpenoids bonducellpin D, caesalmin B and the flavonoid 5,7-dimethoxyflavanone40 -O-beta-d-glucopyranoside have promising binding affinity with Mpro of SARS-CoV-1, SARS-CoV-2 and MERS-CoV with potential values compared with repurposed drugs (43).Other natural metabolites capable of inhibiting the Mpro of SARS-CoV-2 in molecular docking are kaempferol, quercetin, luteolin-7-glucoside, demethoxycurcumin, naringenin, 
apigenin,7-glucoside, oleuropein, catechin, curcumin, and epigallocatechin. The antiviral activity of these flavonoids is beneficial as they can be easily available as they are welldistributed in the angiosperm families, such as Lauraceae, Lamiaceae, Apiaceae, and Leguminosae.

Microbial natural products such as citriquinochroman, holyrine $\mathrm{B}$, proximicin $\mathrm{C}$, pityriacitrin $\mathrm{B},(+)$-anthrabenzoxocinone, penimethavone $\mathrm{A}$ have also been shown high potential to inhibit SARS-CoV-2 Mpro active site by MDS experiments (44).

\section{Spike Glycoprotein}

The spike (S) glycoprotein is a viral transmembrane protein located on the outer envelope of virion responsible for the entry of infectious virion particles inside host cell inducingrobust humoral and cell-mediated immune responses in humans during infection. It has two domains $\mathrm{S} 1$ and S2 for host receptor binding and fusion respectively. Hence, spike glycoprotein considered as a potential target for the attachment inhibitors for the management of COVID19 as receptor binding and membrane fusion are characteristics of spike glycoprotein.

Natural products from Ayurveda are screened that have the potential to block the virus entry in host cells by interfering its interaction with cellular receptor and modulate host immune system via molecular docking. Molecular docking results suggested that curcumin and nimbin exhibited highest binding affinity and interaction energy with spike glycoprotein compared to other natural products and all showed better pharmacologic properties. Curcumin is a phytopolyphenol pigment found in the root of Curcumin longa. It has variety of pharmacological properties such as anti-inflammatory, immunomodulatory, antifungal, and antineoplastic activities etc. Nimbin is a tetracyclic terpenoid,,a limonoid found in Azadirachtaindica. Nimbin is also reported to have anti-inflammatory, antipyretic, fungicidal, antihistamine and antiseptic properties, Nafamostat (spike glycoprotein inhibitor) opted as a control for selected natural products.Also withaferin A, piperine, mangiferin, thebaine, berberine, and andrographolide have significant binding affinities towards spike glycoprotein of SARS-CoV-2 that could be used for spike glycoprotein inhibition of SARSCoV-2 (45).

Glycyrrhizin also known as glycyrrhizic acid (GLR), is a triterpenoid saponin mainly isolated from the roots of the plants Glycyrrhiza glabra has previously used to treat liver diseases and specific cutaneous inflammation and has shown activities against SARS-associated human and animal coronaviruses.The Glycyrrhizin was found to inhibit the cytopathic effect of the SARS coronavirus being non cytotoxic to the host cells.GLR inhibited virus replications but as well as the adsorption and penetration of the virus into cells (46). The mechanism of action was not known at that time but assumed that production of nitrous oxide synthase was responsible for the for the inhibition of virus replications. Recent work shown that the destruction of cholesterol-containing lipid rafts by GLR is important showing that a ganglioside-binding domain of the spike protein of SARSCoV-2 likely plays a role in the surface attachment of the virus to lipid rafts. Chloroquine and hydroxychloroquine combination with GLR inhibited the entry of the virus by membrane destabilizing effect bind as they strongly bind to sialic acids and gangliosides, thereby preventing attachment of the virus by the spike to the gangliosides on the raft platforms. Thus, lipid rafts play a crucial role 
in the life cycle of SARS-coronavirus. The drug shows noticeable anti-inflammatory activity and modulates the immune system through an action on MAPK and Toll-like receptors signalling pathways which can be useful to relieve the respiratory distress syndrome associated to the viral infection. For all these beneficial outcomes GLR is being rapidly tested as an anti-SARS-CoV-2 agent or in combination with other drugs. Glycyrrhizin has also shown promising binding affinity with main protease of SARS-CoV-2 demonstrated by molecular modelling approach (41).

\section{ACE2 Receptor}

SARS-Cov-2 internalization initiates through binding to host cell receptor angiotensinconverting enzyme 2 (ACE2). Therefore, inhibition or modulation of ACE2 regarded as one of the proposed host-based strategies for treatment of SARS-CoV-2.Similar to ACEin natural ACE2 inhibitors screened to combat SARS-CoV-2 are distinguished as alkaloids, flavanols, terpenoids, tannins, flavanones, terpenes, limonoids, lignans, phenolic acids and fatty acids.

Recent finding indicates glycosylated derivates of quercetin such as quercetin-3-glucuronide7-glucosideand quercetin 3-vicianoside, has shown promising inhibitory activity with lower binding energy than $-8.3 \mathrm{kcal} / \mathrm{mol}$ and quercetin has ability to inhibit both ACE and ACE2 (47).The molecular docking of Chinese herb metabolites with the ACE2 against SARS-CoV2 includes baicalin (baicalein-7-O-glucuronide), scutellarin (scutellarein-7- glucuronide), hesperidin, nicotianamine, glycyrrhizin, naringin, naringenin, hesperidin, neohesperidin, and nobiletin are capable of inhibiting it.

Curcumin and nimbin exhibited highest binding affinities and interaction energies with ACE2 receptor as well as withaferin A, piperine, mangiferin, thebaine, berberine, and andrographolide showed significant binding affinities towards ACE2 receptor considering captopril (angiotensin-converting enzyme-2 inhibitor) as control. Therefore, these could be used for ACE2-mediated attachment inhibitions. Along with this resveratrol, quercetin, luteolin, naringenin, zingiberene, and gallic acid have the significant binding affinity towards ACE2 receptor only and can be used as starting material for the synthesis of potent antiviral agents for the prevention and treatment of SARS-CoV-2 (45). Silybin is a major metabolite obtained from Milk thistle seeds (Silybum marianum) have also shown lowest binding affinity considering the inhibition through ACE2 and is previously used as an antiinflammatory agent, chemo-preventive and in the treatment of digestive disorders (48).

\section{TMPRSS2}

After receptor interaction, different host proteases can activate the virus-host cell membrane fusion for subsequent viral genome delivery. The host cell surface transmembrane serine protease 2 (TMPRSS2) activates spike protein present in the SARS-CoV-2.Cleavage of spike protein by TMPRSS 2 is favoured in coronavirus infection over other proteases.SARS-CoV-2 entry is facilitated by TMPRSS2 and using the protease inhibition viral infection is decreased.TMPRSS2 is expressed in different cell types of lung tissue increasing their liability for SARSCoV-2 infections. Therefore,TMPRSS2 has emerged as a potential drug target for COVID-19. 
Despite the fact that molecular docking indicates it as a strategy in COVID-19 treatment TMPRSS2 inhibitions search is the lowest within the major replication proteins.TMPRSS2 natural inhibitors includes terpenes, flavonoids, and peptides (49). Flavonoids baicalein and baicalin were reported as a down-regulators of the TMPRSS-2 expression, Lignans iridoids and diterpenes were also evaluated by in silico studies as potential TMPRSS2 inhibitors.

\section{Other Potential Targets}

RNA-dependent RNA polymerase ( $R d R p)$ facilitates the transcription and replication of RNA genome during infection and with its importance for the virus life cycle makes it as a drug target for antiviral development. The replication-transcription complex in coronavirus is formed after cleavage of the polyproteins ppla and pp $1 \mathrm{ab}$ into non-structural proteins. SARSCoV RdRp need nsp7 and nsp8 as cofactors to stimulate polymerase activity. The association with exoribonuclease lead to the formation of a macromolecular assembly for systematic nucleotide polymerization, proofreading and cap-modifying. This multifunctional protein assembly and the 2-O-methyltransferase coordinate the replication-transcription machinery of SARS-CoV. The non-structural protein 15 have endoribonuclease activity that cleaves preferably at uridine residues. Helicase is an important protein in the replication-transcription complex of coronavirus that catalyses the processive separation of double -stranded DNA and RNA in a $5^{\prime}$-to $-3^{\prime}$ direction. As this protein is essential for the RNA viral synthesis therefore, it is considered as an emerging target for COVID-19.

Natural ligands from NPASS (natural product activity and species source) database were screened against six potential therapeutic targets such as helicase, endoribonuclease, exoribonuclease, RNA-dependent RNA polymerase, N-methyltransferase and Mpro by molecular docking experiment. Compound 2,3,4-trihydroxy benzoic acid, an anti-oxidant showed encouraging dockings scores compared to controls against endoribonuclease, exoribonuclease, RdRp, Methyltransferase and Mpro. Compounds such as astilbin and neostilbin also showed better docking scores against the aforementioned targets. (50). Astilbin is a flavanonol and neostilbin is enantiomer of astilbin. Astilbin have role as a radical scavenger, an anti-inflammatory agent.

Natural molecules as potential leads evaluated by several computational studies for antiviral activity against SARS-CoV-2 targets:

Table 2: Phytochemicals which were evaluated for activity against COVID-19

\begin{tabular}{|l|l|l|l|}
\hline $\begin{array}{r}\text { Sr. } \\
\text { No. }\end{array}$ & \multicolumn{1}{|c|}{ Natural Molecules } & \multicolumn{1}{|c|}{$\begin{array}{c}\text { Target proteins of } \\
\text { SARS-CoV-2 }\end{array}$} & References \\
\hline & $\begin{array}{l}\text { Robustone, SchizolaenoneB } \\
\text { Osajin } \\
1 .\end{array}$ & $\begin{array}{l}\text { Isosilybin A } \\
\text { Silybin A } \\
\end{array}$ & Silydianin \\
& Isopomiferin & Main Protease (Mpro) & $(40)$ \\
\hline 2. & Kaempferol & & \\
\hline
\end{tabular}




\begin{tabular}{|c|c|c|c|}
\hline & $\begin{array}{l}\text { Quercetin } \\
\text { Luteolin-7-glucoside Demethoxycurcumin } \\
\text { Naringenin } \\
\text { Apigenin-7-glucoside } \\
\text { Oleuropein } \\
\text { Curcumin } \\
\text { Catechin } \\
\text { Epicatechin-gallate }\end{array}$ & & \\
\hline 3. & $\begin{array}{l}\text { Bonducellpin-D Caesalmin B } \\
\text { Flavonoid 5,7-dimethoxy flavanone-40 -O- } \\
\text { b-d-glucopyranoside }\end{array}$ & Main Protease (Mpro) & (43) \\
\hline 4. & $\begin{array}{l}\text { Curcumin } \\
\text { Nimbin } \\
\text { Withaferin A } \\
\text { Piperine } \\
\text { Mangiferin } \\
\text { Thebaine } \\
\text { Berberine Andrographolide }\end{array}$ & $\begin{array}{l}\text { Spike glycoprotein } \\
\text { ACE2 receptor }\end{array}$ & $(45)$ \\
\hline 5. & $\begin{array}{l}\text { d-viniferin } \\
\text { Myricitrin Taiwanhomoflavone A } \\
\text { Lactucopicrin 15-oxalate Nympholide A } \\
\text { Afzelin } \\
\text { Biorobin } \\
\text { Hesperidin Phyllaemblicin B }\end{array}$ & $\begin{array}{l}\text { Mpro } \\
\text { RdRp } \\
\text { ACE-2 Receptor }\end{array}$ & $(52)$ \\
\hline 6. & 2,3,4-Trihydroxybenzoic acid & $\begin{array}{l}\text { RdRp } \\
\text { Mpro } \\
\text { Exoribonuclease } \\
\text { Endoribonuclease } \\
\text { Methyltransferase }\end{array}$ & $(50)$ \\
\hline 7. & Astilbin and Neostilbin & $\begin{array}{l}\text { Helicase } \\
\text { Exoribonuclease } \\
\text { Methyltransferase }\end{array}$ & $(50)$ \\
\hline 8. & $\begin{array}{l}\text { Hypericin } \\
\text { Cyanidin-3-glucoside Baicalin } \\
\text { Glabridin } \\
\text { Alpha-ketoamide-11r }\end{array}$ & Mpro & (41) \\
\hline
\end{tabular}

Besides In-Silico approaches, several studies have indicated other promising natural candidates which could be useful in COVID-19 treatment with requirements of further studies are as follows:

- Artemisia annua containing bioactive compound have shown activity against hepatitis B virus, bovine viral diarrhoea virus and Epstein-Barr virus including SARS 
coronavirus and will be of great value if they have efficacy against SARS-COV-2 as they are cheap and easily available. Artemisia annua extract exhibit significant antioxidant activity that is most likely due to its high phenolic content which could be beneficial for pulmonary fibrosis observed in SARS coronavirus-2 (SARS-CoV-2) infection with increased severity, mediated by Interleukin-1 (53).

- The DNA intercalators stabilize double-stranded nucleic acids inhibiting the replication, transcription, and translation of genetic material. These alkaloids have also shown antiviral activity for SARS-CoV-1 and other viruses inhibiting viral development and viral replication in cells. Known DNA intercalators are berberine, emetine, sanguinarine, and other isoquinoline alkaloids, B-carboline, and quinoline alkaloids such as cinchonine, quinine, dictamine and skimmianine. Chloroquine, a chemical derivative of the alkaloid quinine and also a DNA intercalator is apparently clinically helpful against SARS-CoV-2 infections. Hence, it is assumed that intercalating alkaloids or the medicinal plants producing them can be promising candidates for the treatment of coronavirus disease 2019 (COVID-19 (54).

- Phyto-cannabinoids derived from Cannabis sativa, such as cannabidiol (CBD) and 9tetrahydrocannabinol (THC) proposed to inhibit inflammatory and Th1 cytokines and/or promote anti-inflammatory and Th2 immune responses. As COVID-19 causes a respiratory disease with a dominant Th1 and inflammatory immune response makes cannabinoids a potential class of compounds to alleviate COVID-19 symptoms and severity (55).

- Polysaccharides extracted from medicinal plants are gaining attention due to their notable bioactivities such as antioxidant activity, anti-viral activity and immunomodulatory activities. It was illustrated that the immunomodulatory, antiinflammatory, anti-oxidative and regulating gut balance activities of these polysaccharides could play the most efficient roles in the treatment of COVID-19 infected patients. Polysaccharide-based vaccines have the potential to be adjuvants (56).

- The Herpesviruses complications such as inflammation that is induced at the sites of infection and severe respiratory infection is in the same way in which SARS-CoV-2 affects humans. Two naturally occurring alkaloids with notable anti-herpesvirus properties (homoharringtonine and emetine) were evaluated for their ability to effectively inhibit the replication of SARS-CoV-2 in vitro but this study did not established the mechanisms of induced anti-SARS-CoV-2 activity (57).

Modern-day medical science also believes that the decoction having anti-oxidant, antiinflammatory, anti-viral, anti-bacterial, antitussive and anti-fungal properties made from Basil, Cinnamon, Black pepper, Dry Ginger and Raisin drinking once or twice a day is helpful in increasing the immunity and can proveto be a panacea in life of patients as well as preventing from getting infected quickly. Jasadbhasma is Zinc based antiviral drug which is used in various preparations which are seen effective in pulmonary disorders and zinc has antiviral efficacy showing inhibition of RdRp template binding and elongation. 
Recent studies suggested that, Ashwagandha (Indian Winter Cherry) can play a pivotal role in fight against COVID-19 which is considered as one of the essential herbs by Ayurveda for its wide range of benefits. According to the study, Withanone which can be derived from Ashwagandha has the potential to block the viral replication. Regular consumption of Ashwagandha can help us improving immunity and alleviating common problems like cough, cold and respiratory problems which makes it potential remedy for any viral disease. Coronavirus infection reduces the body immunity which can be further weakened by the attack of microorganisms. Use of immunity boosters like I-immune capsules rich with ingredients like triphala, haldi, trikatu, mulethi, papaya leaves, shigru, manjistha, ashwagandha, wheat grass and guduchisatva can help in building and maintaining a rigid immunity wall to fight against COVID-19 virus and also has stress-busting, metabolism and digestion boosting and strong antioxidant properties. Triphala mixture having three main elements such as Amalaki (Embilica officinalis), Bibhitaki (Terminalia bellirica) and Haritaki (Terminalia chebula) has antiviral, antibacterial, anti-inflammatory abilities and immunity boosting capabilities. Phitarkaree (Aluminium sulphate) is a strong astringent and using its solution to gargle can be effective as COVID-19 affects upper respiratory tract or lower respiratory tract.

\section{Regulatory aspects for using natural products as therapeutics}

The use of herbal medicines has increased tremendously in both developed and developing countries being available not only in drug stores but also in food stores and supermarkets as natural therapies has gained public interest and acceptance in primary healthcare. The huge amount of money such as billions of dollars have spent on Over-the-counter herbal products as it is believed that they promote balanced and moderate approach in healing and often used as home remedies. The recent resurgence of public interest in herbal medicines has been attributed to conventional therapies such as pharmaceuticals in some cases have proven to be inadequate or ineffective for certain diseases and due to its high cost and severe side effects. Also, various advertisements including radio and television programmes has given herbal products extreme respectability and credibility which increased consumer awareness. Although some have established promising efficacy, many of them remain inexpedient and their use is poorly monitored because of inadequate knowledge regarding adverse reactions including overdose or toxicity, mode of actions, contraindications, interaction with existing pharmaceuticals and contamination with other products. Safety of most herbal medicines is often compromised by inadequate labelling, lack of suitable quality control and absence of appropriate patient information. They are often considered as non-toxic and with lack of adverse effects and this misconception has led to improper use, unrestrained intake which can be resulted in acute health problems and severe poisoning.

Traditional and herbal medicines are often classified as foods or dietary supplements which does not require evidence of rigorous or controlled quality, safety and efficacy data before marketing and in most of the cases the traditional health practitioners may not be certified or licensed and the natural products are continuously made available without prescription. The providers of medicines have many a times have little training in and understanding of how herbal medicine affect health of patients. Many countries lack effective machinery to regulate 
manufacturing practices and quality standards and introduces product into the market without any safety or toxicological evaluation and these product are continuously made available to consumers without prescriptions and potential hazards in an products are hardly recognized (Ekor, 2014). However, the acquisition of pharmacological information and potential for drug interaction pose a major challenge as there are vast number of plant-based medicines but failure to address can lower ethical standards for those who rely upon herbal medicines. This inevitably generates ethical concerns and thus safe and rational use of herbal remedies are being promoted by taking appropriate measures by regulatory authorities to ensure public health protection.

Table 3: Herbal Drugs and formulations currently under clinical trials for Therapeuticl Prophylactic use against COVID-19 (Source: https://www.iiim.res.in/cured/pipeline.php)

\begin{tabular}{|l|c|c|}
\hline \multicolumn{1}{|c|}{$\begin{array}{c}\text { AYUSH Prophylactics / } \\
\text { Therapeutics }\end{array}$} & $\begin{array}{c}\text { Institutional Ethics Committee } \\
\text { Approval }\end{array}$ & $\begin{array}{c}\text { Safety \& Efficacy } \\
\text { trials }\end{array}$ \\
\hline Withania somnifera & Yes & Ongoing \\
\hline $\begin{array}{l}\text { Tinospora cordifolia + Piper } \\
\text { longum }\end{array}$ & Yes & Ongoing \\
\hline Glycyrrhiza glabra & Yes & Ongoing \\
\hline $\begin{array}{l}\text { Tinospora cordifolia \& Adhatoda } \\
\text { vasica } \\
\text { (individually and in } \\
\text { combination) }\end{array}$ & Yes \\
\hline AYUSH-64 & Yes & Ongoing \\
\hline
\end{tabular}

\section{WHO guidelines}

Regulation of herbal medicines is defined as a principle, rule or law designed to control or govern manufacturers and producers of herbal medicines. For example, a regulation would state that herbal medicines must have been proven to be safe, effective and of good quality before reaching the public (World Health Organization, 2019).

Legal process of regulation and legislation of herbal medicines changes from country to country reason for that mainly cultural aspects and also herbal medicines are rarely studied scientifically. Very few preparations are tested for safety and efficacy (Calixto, 2000). As a demand of herbal drugs is increasing, their safety and quality of the crude drugs and finished products have become a major concern (World Health Organization, 2019), therefore development of guidelines is important to ensure the quality, safety and efficacy of herbal medicines. WHO published guidelines for evaluation of quality, safety, and efficacy of herbal 
medicines and ecological sound cultivation practices (CCRAS, 2018),(Calixto, 2000). WHO also has prepared Pharmacopeial monographs on herbal medicines (Calixto, 2000) and has published guidelines for GACPs (Good agriculture and collection practices) for medicinal plants (World Health Organization, 2019). Manufacturing of herbal medicines requires the existence of Good manufacturing practices (GMP) and regulatory requirements for same. Regulation on manufacturing ensures their quality require adherence to manufacturing information in pharmacopoeias and monographs and same regulations for GMP apply to both herbal and conventional pharmaceuticals. Further they need mechanism to ensure compliance with manufacturing requirement. In china, Good agriculture practices (GAP) for Chinese crude drugs regulations and Good laboratory practices (GLP) compliance programme was issued for drug safety studies that covers both traditional Chinese medicines and conventional pharmaceuticals(World Health Organization, 2019). GACPs includes site selection, climate and soil consideration, seed identification, main post- harvest operation technologies, time of harvest, legal aspects, standardization of cultivation and collection practices (CCRAS, 2018).

Almost equal number of states have an exclusive regulation for herbal medicines or partly same regulation as for conventional pharmaceutical. This is followed by states that follows the same regulation as for Conventional pharmaceuticals. Medical Claims remained the most popular type of claim used for herbal medicines, followed by health claim and nutrient claim(World Health Organization, 2019).

Many people work in healthcare are familiar with framework that is promoted by four principles of beneficence, nonmaleficence, autonomy, and justice. Together all principles engage that healthcare professionals must aim to do good, avoid doing harm, respect the right of individual to make decision for themselves and ensure that are treated fairly. Recently ethical framework has emerged that is based upon globally accepted ethical values of care, respect, honesty, and fairness in relation to herbal medicines. Considering care practitioners requires knowledge and expertise and must ensure that indicated medication is appropriate and safe as inaccurate information can lead to harm for patients. Ethical framework can be used to reveal challenges for herbal medicine and also to suggest strategies for enhancing ethical standards in production, education, and practice of herbal medicine (Chatfield, Salehi, Sharifi-Rad, \& Afshar, 2018).

\section{Economic aspects related to using Natural products as an alternative to modern synthetic drugs}

The Covid-19 crisis is taking its toll on the global economy, our health and in our life. Millions of people are being infected worldwide, which has led the governments of various nations to take drastic measures to limit the spread of the virus. This has led to a drastic decline in various economic activities all around the world. As cases and deaths are rising doctors and researchers has been trying out range of treatments, since 2019 various researches and experiments are conducted in different fields of medicine. Doctors are prescribing fistful of alternative drugs, to fight the virus. As no vaccine and cure is still available, the main focus is to fight the symptoms. 


\section{Conclusion}

Since December 2019 we are facing this deadly virus. Currently, COVID-19 has appeared as one of the most forceful and terrifying viral infectious disease to be contain by the human civilisation. By November 6, 2020 around 49.5 million COVID-19 cases have been reported. The spread of this infectious and contagious disease is very high. All the major and minor stakeholders of the health care system are engaged to prevent further spread of this disease. Along with rendezvous efforts of several researchers and industrial scientists to bring the effective cure against COVID-19 for the masses. As a matter of fact, several vaccine trials are on the go with expedite regulatory and approval process. Which is also true for the synthetic molecules who are proceeding with the fast drug repurposing processes. Computational drug design and preventive medicines are also evolving in a speedy manner like never before. In the league of this herculin research scenario plant-based drugs and phytochemicals are no more unwaged. In fact, with the advancement in computational drug development, analytical technologies, and effective isolation methodologies the phytochemicals are rising as up with a charm to potentially cure the COVID-19. The approach of these natural constituents is not only limited to COVID-19 rather this infectious virus unearthed the real aura of the phytochemicals in the modern era of health science and evidence-based medicine. 


\section{References:}

1. McCreary EK, Pogue JM. Coronavirus disease 2019 treatment: a review of early and emerging options. In Oxford University Press US; 2020. p. ofaa105.

2. Saha A, Sharma AR, Bhattacharya M, Sharma G, Lee S-S, Chakraborty C. Probable Molecular Mechanism of Remdesivir for the Treatment of COVID-19: Need to Know More. Arch Med Res [Internet]. 2020 May 12 [cited 2020 Jul 7]; Available from: http://www.sciencedirect.com/science/article/pii/S0188440920306998

3. Holshue ML, DeBolt C, Lindquist S, Lofy KH, Wiesman J, Bruce H, et al. First case of 2019 novel coronavirus in the United States. N Engl J Med. 2020;

4. Wang M, Cao R, Zhang L, Yang X, Liu J, Xu M, et al. Remdesivir and chloroquine effectively inhibit the recently emerged novel coronavirus $(2019-\mathrm{nCoV})$ in vitro. Cell Res. 2020 Mar;30(3):269-71.

5. Colson P, Rolain J-M, Lagier J-C, Brouqui P, Raoult D. Chloroquine and hydroxychloroquine as available weapons to fight COVID-19. Int J Antimicrob Agents. 2020 Apr;55(4):105932.

6. Quiros Roldan E, Biasiotto G, Magro P, Zanella I. The possible mechanisms of action of 4-aminoquinolines (chloroquine/hydroxychloroquine) against Sars-Cov-2 infection (COVID-19): A role for iron homeostasis? Pharmacol Res. 2020 Aug 1;158:104904.

7. Owa AB, Owa OT. Lopinavir/ritonavir use in Covid-19 infection: is it completely nonbeneficial? J Microbiol Immunol Infect [Internet]. 2020 May 25 [cited 2020 Jul 9]; Available from: http://www.sciencedirect.com/science/article/pii/S1684118220301286

8. Lopinavir/ritonavir: A rapid review of effectiveness in COVID-19 [Internet]. CEBM. [cited $2020 \mathrm{Jul}$ 9]. Available from: https://www.cebm.net/covid-19/lopinavir-ritonavira-rapid-review-of-the-evidence-for-effectiveness-in-treating-covid/

9. Rossignol J-F. Nitazoxanide, a new drug candidate for the treatment of Middle East respiratory syndrome coronavirus. J Infect Public Health. 2016 May 1;9(3):227-30.

10. Dang W, Xu L, Ma B, Chen S, Yin Y, Chang K-O, et al. Nitazoxanide Inhibits Human Norovirus Replication and Synergizes with Ribavirin by Activation of Cellular Antiviral Response. Antimicrob Agents Chemother [Internet]. 2018 Nov 1 [cited 2020 Jul 9];62(11). Available from: https://aac.asm.org/content/62/11/e00707-18

11. Tocilizumab in the Treatment of Coronavirus Induced Disease (COVID-19) - Full Text View - ClinicalTrials.gov [Internet]. [cited 2020 Jul 9]. Available from: https://clinicaltrials.gov/ct2/show/NCT04335071

12. Veronese N, Demurtas J, Yang L, Tonelli R, Barbagallo M, Lopalco P, et al. Use of Corticosteroids in Coronavirus Disease 2019 Pneumonia: A Systematic Review of the Literature. Front Med [Internet]. 2020 [cited 2020 Jul 9];7. Available from: https://www.frontiersin.org/articles/10.3389/fmed.2020.00170/full

13. PhD NRG. Interferon Responses Could Explain Susceptibility to Severe COVID-19 [Internet]. Medium. 2020 [cited 2020 Jul 9]. Available from: 
https://medium.com/swlh/interferon-responses-could-explain-susceptibility-to-severecovid-19-cc69a654b999

14. COVID-19 treatment: Scientists say brand new flu drug might help in reducing viral load, prevent SARS-CoV-2 transmission - Health News , Firstpost [Internet]. Firstpost. 2020 [cited $2020 \mathrm{Jul}$ 9]. Available from: https://www.firstpost.com/health/covid-19treatment-scientists-say-brand-new-flu-drug-might-help-in-reducing-viral-load-preventsars-cov-2-transmission-8444701.html

15. Gao Y, Yan L, Huang Y, Liu F, Zhao Y, Cao L, et al. Structure of the RNA-dependent RNA polymerase from COVID-19 virus. Science. 2020 May 15;368(6492):779-82.

16. Mokobi F. Favipiravir- properties, uses, mechanism, side effects, COVID-19 [Internet]. Microbe Notes. 2020 [cited 2020 Jul 9]. Available from:

https://microbenotes.com/favipiravir/

17. Silver lining despite rise in Delhi's coronavirus cases [Internet]. Hindustan Times. 2020 [cited 2020 Jul 8]. Available from: https://www.hindustantimes.com/delhi-news/silverlining-despite-delhi-coronavirus-cases-rise/story-YHjNdIzQfvRoJrlvbB8snJ.html

18. Huet T, Beaussier H, Voisin O, Jouveshomme S, Dauriat G, Lazareth I, et al. Anakinra for severe forms of COVID-19: a cohort study. Lancet Rheumatol. $2020 \mathrm{Jul}$ $1 ; 2(7): \mathrm{e} 393-400$.

19. India's CDRI gets approval for Umifenovir trial in Covid-19 treatment [Internet]. Pharmaceutical Technology. 2020 [cited 2020 Jul 9]. Available from:

https://www.pharmaceutical-technology.com/news/indias-cdri-trial-umifenovir-covid$19 /$

20. Vankadari N. Arbidol: A potential antiviral drug for the treatment of SARS-CoV-2 by blocking trimerization of the spike glycoprotein. Int J Antimicrob Agents. 2020 Apr $28 ; 105998$.

21. D'Onofrio K. Lilly Announces Phase 3 Clinical Trial of Baricitinib for COVID-19 Patients [Internet]. Docwire News. 2020 [cited 2020 Jul 9]. Available from: https://www.docwirenews.com/docwire-pick/rheumatology-picks/eli-lilly-announcesphase-3-clinical-trial-of-baricitinib-for-covid-19-patients/

22. Rosa SGV, Santos WC. Clinical trials on drug repositioning for COVID-19 treatment. Rev Panam Salud Pública [Internet]. 2020 Mar 20 [cited 2020 Jul 9];44. Available from: https://www.ncbi.nlm.nih.gov/pmc/articles/PMC7105280/

23. Brilacidin [Internet]. Innovation Pharmaceuticals Inc. [cited 2020 Jul 9]. Available from: http://www.ipharminc.com/brilacidin-1

24. Effect of Convalescent Plasma Therapy on Time to Clinical Improvement in Patients With Severe and Life-threatening COVID-19 [Internet]. [cited 2020 Jul 9]. Available from: https://www.ncbi.nlm.nih.gov/pmc/articles/PMC7270883/ 
25. Lin M-H, Moses DC, Hsieh C-H, Cheng S-C, Chen Y-H, Sun C-Y, et al. Disulfiram can inhibit MERS and SARS coronavirus papain-like proteases via different modes. Antiviral Res. 2018 Feb 1;150:155-63.

26. A Study to Evaluate Efficacy and Safety of Darunavir/Cobicistat/Emtricitabine/Tenofovir Alafenamide (D/C/F/TAF) Fixed Dose Combination (FDC) Versus a Regimen Consisting of Darunavir/Cobicistat FDC With Emtricitabine/Tenofovir Disoproxil Fumarate FDC in Treatment-naive HIV Type 1 Infected Subjects [Internet]. AIDSinfo. [cited 2020 Jul 9]. Available from: https://aidsinfo.nih.gov/clinical-trials/details/NCT02431247

27. Diurno F, Numis FG, Porta G, Cirillo F, Maddaluno S, Ragozzino A, et al. Eculizumab treatment in patients with COVID-19: preliminary results from real life ASL Napoli 2 Nord experience. Eur Rev Med Pharmacol Sci. 2020;24(7):4040-7.

28. BioCryst | Oral Drugs for Viruses | Galidesivir [Internet]. BioCryst Pharmaceuticals. [cited 2020 Jul 9]. Available from: http://www.biocryst.com/our-program/galidesivir/

29. Musarrat F, Chouljenko V, Dahal A, Nabi R, Chouljenko T, Jois SD, et al. The anti-HIV drug nelfinavir mesylate (Viracept) is a potent inhibitor of cell fusion caused by the SARSCoV-2 spike (S) glycoprotein warranting further evaluation as an antiviral against COVID-19 infections. J Med Virol [Internet]. [cited $2020 \mathrm{Jul}$ 9];n/a(n/a). Available from: https://onlinelibrary.wiley.com/doi/abs/10.1002/jmv.25985

30. Elfiky AA. Anti-HCV, nucleotide inhibitors, repurposing against COVID-19. Life Sci. 2020 May 1;248:117477.

31. Boretti A, Banik BK. Intravenous vitamin C for reduction of cytokines storm in acute respiratory distress syndrome. Pharmanutrition. 2020 Jun;12:100190.

32. Jácome R, Campillo-Balderas JA, Ponce de León S, Becerra A, Lazcano A. Sofosbuvir as a potential alternative to treat the SARS-CoV-2 epidemic. Sci Rep. 2020 Jun 9;10(1):9294.

33. Sanofi: Press Releases, Monday, April 27, 2020 [Internet]. https://www.sanofi.com/en/media-room/press-releases/2020/2020-04-27-12-58-00. [cited $2020 \mathrm{Jul}$ 9]. Available from: https://www.sanofi.com/media-room/pressreleases/2020/2020-04-27 12-58-00 2022288

34. Rizzo E. Ivermectin, antiviral properties and COVID-19: a possible new mechanism of action. Naunyn Schmiedebergs Arch Pharmacol. 2020 Jul 1;393(7):1153-6.

35. Recommendation regarding the use of Ivermectin as a treatment for COVID-19 PAHO/WHO | Pan American Health Organization [Internet]. [cited 2020 Jul 9]. Available from: https://www.paho.org/en/documents/recommendation-regarding-useivermectin-treatment-covid-19

36. WHO discontinues hydroxychloroquine and lopinavir/ritonavir treatment arms for COVID-19 [Internet]. [cited 2020 Jul 9]. Available from: https://www.who.int/newsroom/detail/04-07-2020-who-discontinues-hydroxychloroquine-and-lopinavir-ritonavirtreatment-arms-for-covid-19 
37. Winslow LC, Kroll DJ. Herbs as Medicines. Arch Intern Med. 1998 Nov 9;158(20):2192-9.

38. Sen S, Chakraborty R. Revival, modernization and integration of Indian traditional herbal medicine in clinical practice: Importance, challenges and future. J Tradit Complement Med. 2016 Jun 28;7(2):234-44.

39. Mani JS, Johnson JB, Steel JC, Broszczak DA, Neilsen PM, Walsh KB, et al. Natural product-derived phytochemicals as potential agents against coronaviruses: A review. Virus Res. 2020 Jul;284:197989.

40. Rasool N, Akhtar A, Hussain W. Insights into the inhibitory potential of selective phytochemicals against Mpro of 2019-nCoV: a computer-aided study. Struct Chem [Internet]. 2020 May 1 [cited 2020 Jul 13]; Available from: http://link.springer.com/10.1007/s11224-020-01536-6

41. Islam R, Parves MdR, Paul AS, Uddin N, Rahman MdS, Mamun AA, et al. A molecular modeling approach to identify effective antiviral phytochemicals against the main protease of SARS-CoV-2. J Biomol Struct Dyn. 2020 May 12;1-12.

42. Chaudhari RN, L.Khan S, Chaudhary RS, Jain SP, Sidduqui FA. B-SITOSTEROL: ISOLATION FROM MUNTINGIA CALABURA LINN BARK EXTRACT, STRUCTURAL ELUCIDATION AND MOLECULAR DOCKING STUDIES AS POTENTIAL INHIBITOR OF SARS-CoV-2 Mpro (COVID-19). Asian J Pharm Clin Res. 2020 May 2;204-9.

43. Gurung AB, Ali MA, Lee J, Farah MA, Al-Anazi KM. Unravelling lead antiviral phytochemicals for the inhibition of SARS-CoV-2 Mpro enzyme through in silico approach. Life Sci. 2020 Aug;255:117831.

44. Sayed AM, Alhadrami HA, El-Gendy AO, Shamikh YI, Belbahri L, Hassan HM, et al. Microbial Natural Products as Potential Inhibitors of SARS-CoV-2 Main Protease (Mpro). Microorganisms. 2020 Jun 29;8(7):970.

45. Maurya VK, Kumar S, Prasad AK, Bhatt MLB, Saxena SK. Structure-based drug designing for potential antiviral activity of selected natural products from Ayurveda against SARS-CoV-2 spike glycoprotein and its cellular receptor. VirusDisease. 2020 Jun;31(2):179-93.

46. Bailly C, Vergoten G. Glycyrrhizin: An alternative drug for the treatment of COVID-19 infection and the associated respiratory syndrome? Pharmacol Ther. 2020 Oct;214:107618.

47. Joshi T, Joshi T, Sharma P, Mathpal S, Pundir H, Bhatt V, et al. In silico screening of natural compounds against COVID-19 by targeting Mpro and ACE2 using molecular docking. Eur Rev Med Pharmacol Sci. 2020 Apr;24(8):4529-36.

48. Pandit M, Latha N. In silico studies reveal potential antiviral activity of phytochemicals from medicinal plants for the treatment of COVID-19 infection [Internet]. In Review; 2020 Apr [cited $2020 \mathrm{Jul} 13$ ]. Available from: https://www.researchsquare.com/article/rs-22687/v1 
49. Antonio A da S, Wiedemann LSM, Veiga-Junior VF. Natural products' role against COVID-19. RSC Adv. 2020;10(39):23379-93.

50. Naik B, Gupta N, Ojha R, Singh S, Prajapati VK, Prusty D. High throughput virtual screening reveals SARS-CoV-2 multi-target binding natural compounds to lead instant therapy for COVID-19 treatment. Int J Biol Macromol. 2020 Oct;160:1-17.

51. Khaerunnisa S, Kurniawan H, Awaluddin R, Suhartati S, Soetjipto S. Potential Inhibitor of COVID-19 Main Protease (M ${ }^{\text {pro }}$ ) From Several Medicinal Plant Compounds by Molecular Docking Study [Internet]. MEDICINE \& PHARMACOLOGY; 2020 Mar [cited 2020 Jul 13]. Available from:

https://www.preprints.org/manuscript/202003.0226/v1

52. Joshi RS, Jagdale SS, Bansode SB, Shankar SS, Tellis MB, Pandya VK, et al. Discovery of potential multi-target-directed ligands by targeting host-specific SARS-CoV-2 structurally conserved main protease. J Biomol Struct Dyn. 2020 May 5;1-16.

53. Haq FU, Roman M, Ahmad K, Rahman SU, Shah SMA, Suleman N, et al. ARTEMISIA ANNUA : Trials are needed for COVID -19. Phytother Res. 2020 May 27;ptr.6733.

54. Wink M. Potential of DNA Intercalating Alkaloids and Other Plant Secondary Metabolites against SARS-CoV-2 Causing COVID-19. Diversity. 2020 Apr 30;12(5):175.

55. Mamber SW, Krakowka S, Osborn J, Saberski L, Rhodes RG, Dahlberg AE, et al. Can Unconventional Immunomodulatory Agents Help Alleviate COVID-19 Symptoms and Severity? Rosenberg HF, editor. mSphere. 2020 May 13;5(3):e00288-20, /msphere/5/3/mSphere288-20.atom.

56. Cao P, Wu S, Wu T, Deng Y, Zhang Q, Wang K, et al. The important role of polysaccharides from a traditional Chinese medicine-Lung Cleansing and Detoxifying Decoction against the COVID-19 pandemic. Carbohydr Polym. 2020 Jul;240:116346.

57. Hassan STS. Shedding Light on the Effect of Natural Anti-Herpesvirus Alkaloids on SARS-CoV-2: A Treatment Option for COVID-19. Viruses. 2020 Apr 23;12(4):476. 


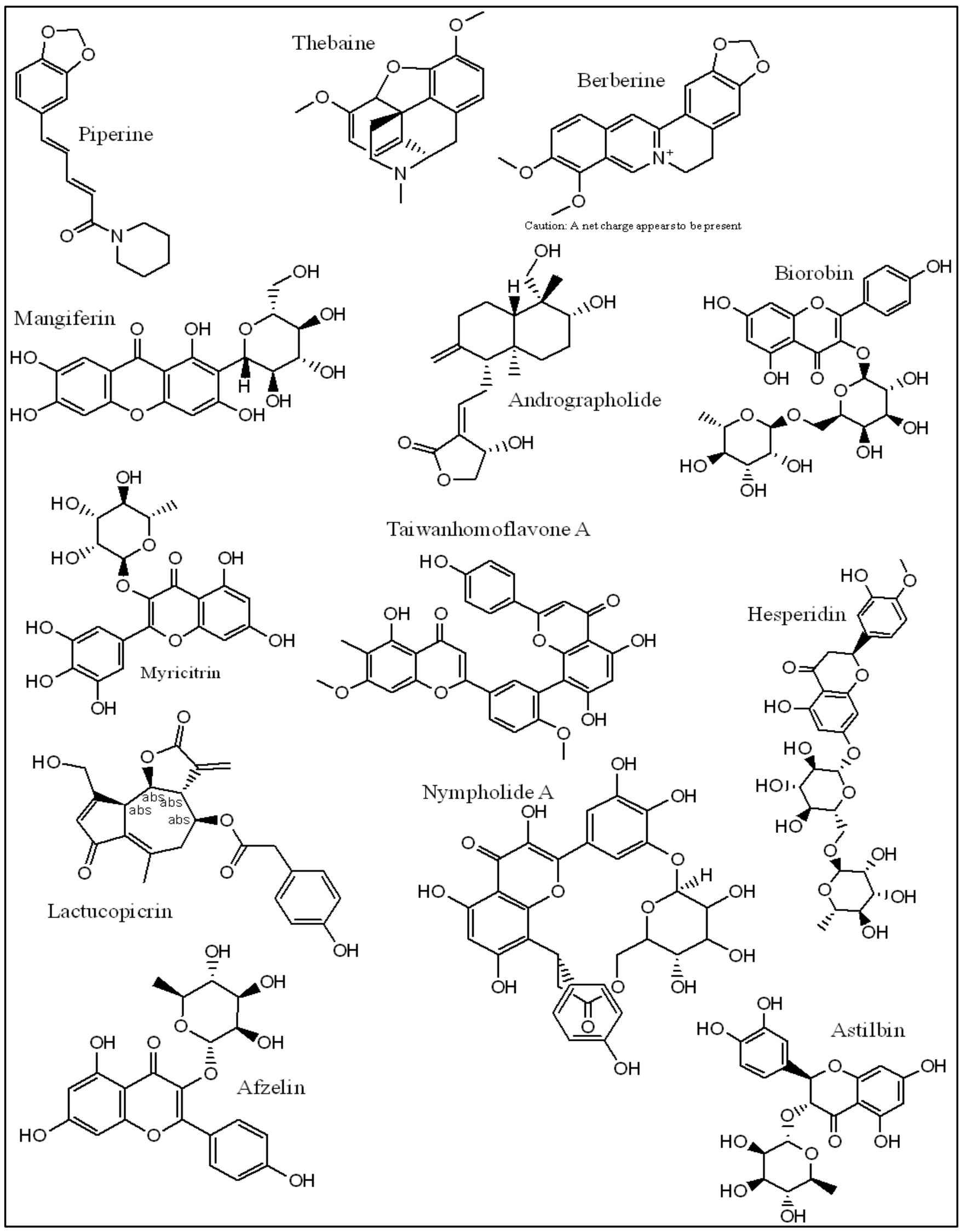

Figure 3: Chemical Structures of Phytochemicals active against COVID-19 (Part 1 of 2) 


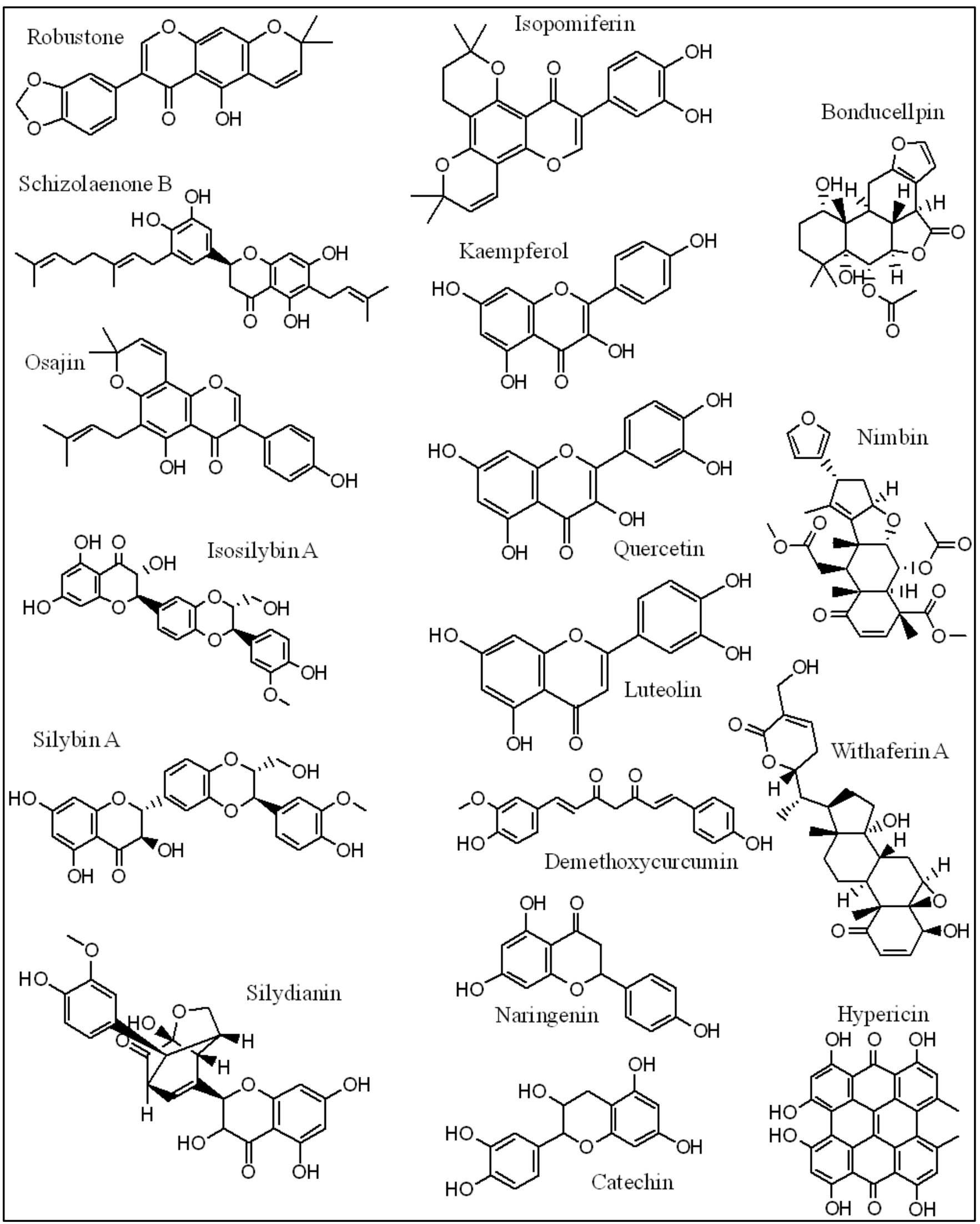

Figure 4: Chemical Structures of Phytochemicals active against COVID-19 (Part 2 of 2) 
Are herbal drugs effective in COVID management? A review to demystify the current facts and claims

Page 31 of 31 